\title{
Performance of the Automated COBAS AmpliPrep/ COBAS TaqMan HIV-1 Test on a Genetically Diverse Panel of Specimens from China: Comparison to the COBAS Amplicor HIV-1 Monitor Test, v1.5
}

\author{
Sihong Xu Aijing Song Xiuhua Li Jianhui Nie Chuntao Zhang \\ Youchun Wang \\ Department of Cell Biology, National Institute for the Control of Pharmaceutical and Biological Products, \\ Beijing, PR China
}

\section{Key Words}

COBAS AmpliPrep/COBAS TaqMan HIV-1 Test • Cobas

Amplicor $\cdot$ HIV-1 $\cdot$ Viral load $\cdot$ Clade

\begin{abstract}
Objectives: To investigate the impact of genetically diverse HIV samples from China on the performance of the automated COBAS $^{\circledR}$ AmpliPrep/COBAS TaqMan ${ }^{\circledR}$ HIV-1 Test (CAP) CTM). Methods: 185 samples from untreated HIV-1-infected patients were used to assess the performance of the CAP/ CTM Test and COBAS Amplicor HIV-1 Monitor Test, v1.5 (Cobas). Results: A comparison of the qualitative results of both assays showed concordance for 1 negative and 184 positive samples $(100 \%, \kappa=1.000)$. A significant correlation $(R=$ $0.862, p<0.001)$ and high agreement $(95.53 \%)$ was observed for 179 samples with viral loads within the dynamic ranges of both assays. For samples of clades predominant in China, the fitted regression line differed significantly from the line of equality, although significant correlations $(R=0.694-$ 0.899, $\mathrm{p}<0.05$ ) and high agreements (91.30-95.35\%) were found for the two assays. The mean differences for samples from clades $B^{\prime}$ and $B C$ were significant $(p<0.001)$ whilst no great difference (7.19-10.88\%) between the quantitative val-
\end{abstract}

\section{KARGER}

Fax +41613061234 E-Mail karger@karger.ch www.karger.com
(C) 2010 S. Karger AG, Basel

0300-5526/10/0534-0221\$26.00/0

Accessible online at:

www.karger.com/int ues for both assays was found by plotting the regression line. Conclusion: The viral loads of different HIV genotypes in China measured by the CAP/CTM and Cobas assays were comparable.

Copyright ๑ 2010 S. Karger AG, Basel

\section{Introduction}

Human immunodeficiency virus type $1(\mathrm{HIV}-1)$ is the etiologic agent of acquired immunodeficiency syndrome (AIDS). It can be transmitted by three means: sexual contact; exposure to infected blood products, and vertical, mother-to-child transmission $[1,2]$. After exposure to HIV-1, the level of HIV-1 RNA in the infected individual varies at different stages of disease progression. With the introduction of highly active antiretroviral therapy for these individuals, the HIV-1 RNA levels markedly and rapidly decreased [3-5]. Therefore, HIV-1 viral load is used as a marker to predict disease progression and to monitor the efficiency of antiretroviral therapy (ART) in $\mathrm{HIV}$-infected individuals. In order to initiate ART, monitor the efficacy of antiretroviral drugs and change therapeutic regimens, it is essential to measure HIV-1 RNA

Dr. Youchun Wang, MD, $\mathrm{PhD}$

Department of Cell Biology

National Institute for the Control of Pharmaceutical and Biological Products No. 2 Tiantanxili, Beijing 100050 (PR China)

Tel. +86106709 5415, Fax +86 106511 3538, E-Mail wangyc@ nicpbp.org.cn 
levels with commercially available HIV-1 viral load assays. These assays should be specific, possess a broad dynamic range, and not be impacted upon by the different clades of HIV-1.

Phylogenetic analyses of HIV gene sequences from around the world indicate that the genome of HIV-1 exhibits high genetic diversity, and that the prevalence of HIV-1 clades, including subtypes and circulating recombinant forms (CRFs), varies in different regions [6]. HIV1 group $\mathrm{M}$, including 9 subtypes designated $\mathrm{A}-\mathrm{J}$ and over 45 CRFs. predominates in many regions around the world. HIV-1 group $\mathrm{N}$ is only found in Cameroon, while the relatively rare group $\mathrm{O}$ is mainly concentrated in western Africa. In China, subtypes A, B, B', C, D and F, and CRF 07_BC, CRF 08_BC, CRF 01_AE, and CRF $02 \_A G$ have been identified amongst the population. However, the predominant HIV-1 clades in China are subtype B', CRF BC and AE, accounting for more than $95 \%$ of the HIV-1 clades prevalent in China [7-10], and are quite different from those in Western countries.

The current commercially available assays for measuring HIV viral loads were developed on the basis of different technologies, including reverse transcriptase-polymerase chain reaction (RT-PCR), nucleic acid sequencebased amplification, branched-DNA (bDNA) signal amplification, ligase chain reaction and TaqMan real-time RT-PCR [11-14]. Real-time RT-PCR offers the advantages of broad dynamic range, simplicity, reduced total testing time, and diminished risk of contamination. It is an ideal method to combine with an automated procedure for sample preparation (nucleic acid extraction) as automation significantly increases throughput whilst reducing the hands-on time required and operator-associated errors.

Recently, a new automated system for monitoring HIV-1 viral loads, namely the COBAS ${ }^{\circledR}$ AmpliPrep/ COBAS TaqMan ${ }^{\circledR}$ HIV-1 Test (CAP/CTM test; Roche Diagnostics, France), which combines automated sample preparation and amplification/detection on a fully integrated platform was approved by the United States Food and Drug Administration. Several studies on the performance of the CAP/CTM test against the COBAS Amplicor HIV-1 Monitor Test, v1.5 (Cobas), an earlier semiautomated assay, for HIV-1 M samples from Western countries have been completed $[15,16]$, and the results indicated a significant correlation between the two assays; however, the predominant clades of HIV-1 in China differ from Western countries, and the issue of whether the clades prevalent in China would impact upon the performances of the CAP/CTM and Cobas assays is also un- clear. In the present study, 185 clinical samples with clades prevalent in China from untreated HIV-1-infected patients were used to evaluate the performance of the CAP/CTM and Cobas assays.

\section{Materials and Methods}

Clinical Samples and Their Molecular Characteristics

A total of 185 plasma samples were collected from untreated HIV-1-infected individuals in different geographical regions of China, including Beijing municipality, Xinjiang Autonomous Region, and Yunnan, Henan, Hubei, Hebei, Sichuan and Guangdong provinces. Among the 185 samples, 147 samples were successfully genotyped based on the env regions as described by Wang et al. [17]. Of these genotyped samples, 47 belonged to clade B', 86 belonged to clade $\mathrm{BC}$ and 14 samples belonged to clade AE. The remaining 38 samples, which could not be genotyped based on the env region, were designated as the unsubtyped group. All 185 samples were stored in the presence of the anticoagulant, sodium citrate, dispensed into $0.5-\mathrm{ml}$ aliquots, and stored at $-70^{\circ}$ until ready for use.

To determine the HIV-1 viral load, all 185 samples were tested with the CAP/CTM and Cobas assays in parallel, then the performance of the two assays was comparatively evaluated.

HIV-1 Viral Load Determination Using CAP/CTM Test

The CAP/CTM test applies TaqMan technology, targeting the gag 24 gene of HIV-1. RNA was extracted from 1-ml plasma samples following the automated specimen preparation procedure, outlined by the manufacturer of the COBAS AmpliPrep Instrument (Roche, France). HIV-1 quantitation standard (QS) armored RNA molecules were introduced into each specimen along with a lysis reagent and magnetic glass particles by robotic manipulation on the COBAS AmpliPrep Instrument. The processed specimen containing the magnetic glass particles as well as the released HIV-1 RNA and HIV-1 QS RNA was added to the amplification mixture automatically. The amplification mixtures were manually transferred to a COBAS TaqMan 96 Analyzer. The HIV-1 target RNA and HIV-1 QS RNA were reverse-transcribed, amplified and simultaneously detected by cleavage of target-specific and QS-specific dual-labeled oligonucleotide probes. According to the package insert, the dynamic range of the assay is $40-10,000,000$ copies/ml (1.833-7.230 $\log _{10} \mathrm{IU} / \mathrm{ml}$, calculated using a conversion factor indicated in the manufacturer's instructions) for $1,000-\mu l$ plasma samples.

HIV-1 Viral Load Determination Using Cobas Assay

The Cobas Amplicor HIV-1 Monitor Test, v1.5 (Roche Molecular Systems, USA) is a standard semi-automated in vitro nucleic acid amplification assay, consisting of manual sample preparation (extraction of HIV-1 RNA) and automated amplification and detection steps on a Cobas Amplicor Analyzer. Like the CAP/ CTM assay, this test targets the gag p24 gene of HIV-1 [18] and co-processes an appropriate QS for accurate quantification. When standard specimen preparation procedures are used, the linear range of the Cobas assay is $4 \times 10^{2}-7.5 \times 10^{5}$ copies $/ \mathrm{ml}$ (2.894-6.167 $\left.\log _{10} \mathrm{IU} / \mathrm{ml}\right)$ and requires $200 \mu \mathrm{l}$ of plasma [14]. 


\section{Statistical Analysis}

According to the conversion factors indicated in the package insert of CAP/CTM and Cobas assays ( 1 copy/ml is equivalent to 1.7 and $1.96 \mathrm{IU} / \mathrm{ml}$ for CAP/CTM and Cobas assays, respectively), all plasma HIV-1 RNA concentration values expressed as copies per milliliter were transformed into international units per milliliter and then transformed into $\log _{10} \mathrm{IU} / \mathrm{ml}$ before statistical analysis. The mean and standard deviation (SD) were calculated using conventional statistical methods. A paired $\chi^{2}$ test $(\mathrm{McNe}-$ mar's $\chi^{2}$ test) and $\kappa$ values were used to qualitatively assess differences between the performance characteristics of the CAP/CTM and Cobas assays. Pearson's correlation coefficient was used to assess the strength of the linear association between the $\log _{10}$ transformed levels in samples assessed as positive by the two assays. To compare the quantitative results obtained for the positive samples detected by both assays, a fitted regression line was compared with the line of equality by testing the two-tailed hypothesis of slope $=1$ and intercept $=0$. According to the Bland-Altman method, a scatter plot of the differences between the paired measurements plotted against the mean values of the samples, was used to graphically assess the magnitude of disagreement between the two assays [19].

\section{Results}

\section{Viral Load Determination}

Of the 185 samples, 184 (99.46\%) were qualitatively assessed as positive for HIV-1 RNA whilst 1 sample (0.54\%), although confirmed as positive for anti-HIV antibodies, was determined to be negative for the presence of HIV-1 RNA using both assays. Hence, the qualitative comparison of the results of the two assays for the 185 samples revealed concordance for 184 positive and 1 negative sample $(100 \%, \kappa=1.000)$. No discordance was found in these qualitative results (McNemar's $\mathrm{p}=1.000)$. The viral loads of the184 positive samples were within the dynamic range for the CAP/CTM assay; however, 5 of these positive samples were beyond the dynamic range for the Cobas assay. The viral load values within the dynamic range for both assays were 2.395-6.451 $\log _{10} \mathrm{IU} / \mathrm{ml}$ for the CAP/ CTM assay and 2.994-6.063 $\log _{10} \mathrm{IU} / \mathrm{ml}$ for the Cobas assay.

\section{Performance Comparison of the Cobas and \\ CAP/CTM Assays}

A total of 179 clinical samples with viral loads within the dynamic range for both assays were used to compare the performance of the CAP/CTM and Cobas assays. A high linear correlation was found between the two assays $(\mathrm{R}=0.862, \mathrm{p}<0.001)$. The fitted regression line (fig. 1) is described by the equation $\mathrm{CAP} / \mathrm{CTM}=0.9518 \times \mathrm{Co}-$ bas -0.1805 , with a $95 \%$ CI for the estimated slope of

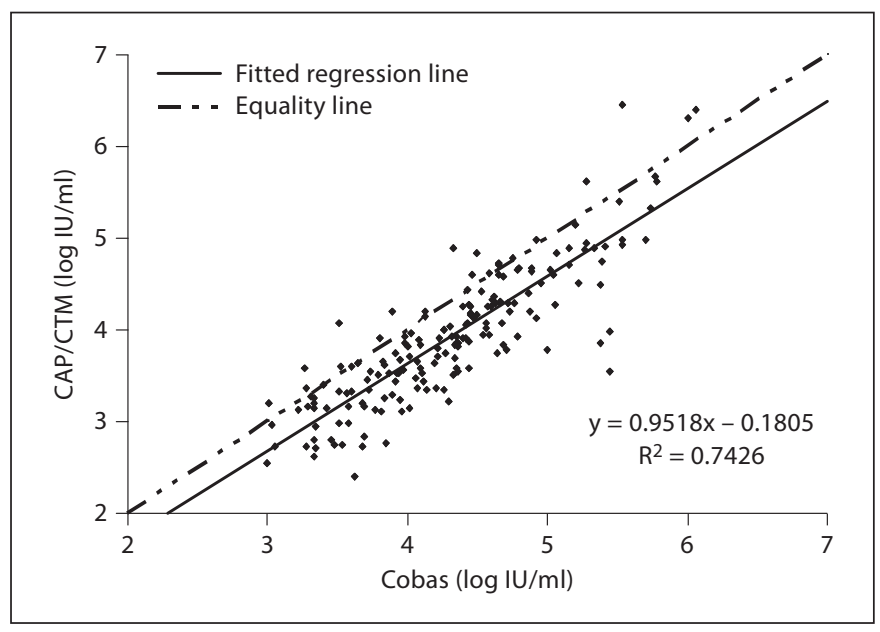

Fig. 1. Linear relationship between CAP/CTM and Cobas Amplicor for 179 samples. The fitted regression line is described by the equation: CAP/CTM $=0.9518 \times$ Cobas $-0.1805, R=0.862$. The solid line represents the fitted regression line and the dashed line represents a perfect match between the two assays.

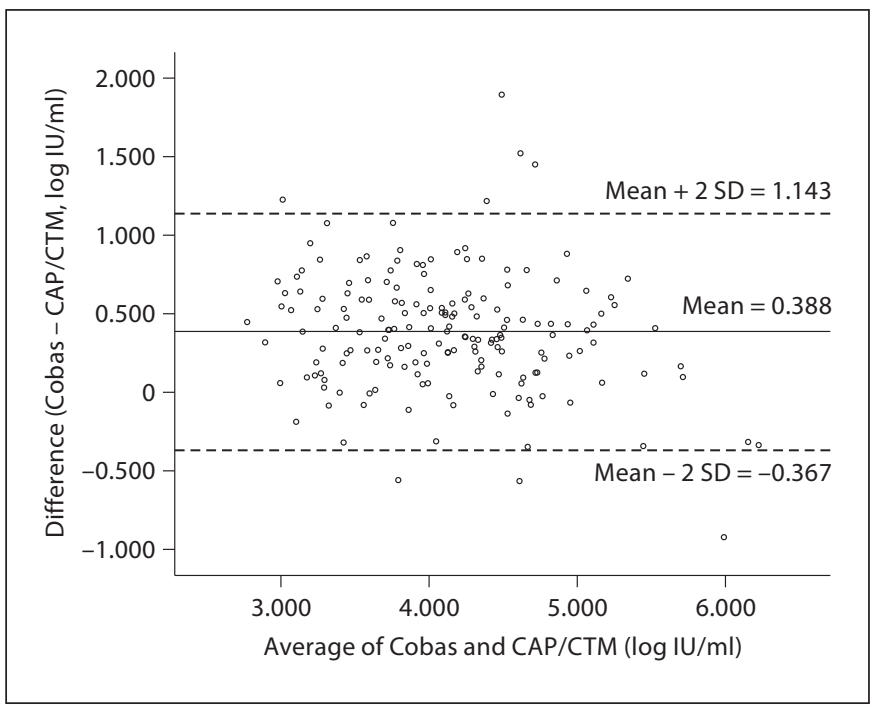

Fig. 2. Agreement between the Cobas and CAP/CTM assays for 179 samples according to the Bland-Altman model.

$0.712,0.848(\mathrm{p}<0.001)$ and $95 \% \mathrm{CI}$ for the estimated intercept of $0.978,1.522(\mathrm{p}<0.001)$. Furthermore, the agreement between the viral loads assessed by the two assays was analyzed for the 179 samples using the Bland-Altman model (fig. 2). The difference in viral load for each sample $\left(\log _{10} \mathrm{IU} / \mathrm{ml}\right.$ Cobas $-\log _{10} \mathrm{IU} / \mathrm{ml}$ CAP/CTM) was plotted 
Table 1. Relationships of the two assays for quantifying HIV-1 RNA from different clades

\begin{tabular}{lrllll}
\hline & $\mathrm{n}$ & $\mathrm{R}$ & Regression equation & $\begin{array}{l}\text { 95\% CI for the } \\
\text { estimated intercept }\end{array}$ & $\begin{array}{l}\text { 95\% CI for the estimated } \\
\text { slope }\end{array}$ \\
\hline Total & 179 & $0.862(\mathrm{p}<0.001)$ & $\mathrm{y}=0.9518 \mathrm{x}-0.1805$ & $0.978,1.522(\mathrm{p}<0.001)$ & $0.712,0.848(\mathrm{p}<0.001)$ \\
B' & 46 & $0.899(\mathrm{p}<0.001)$ & $\mathrm{y}=1.0458 \mathrm{x}-0.535$ & $0.795,1.758(\mathrm{p}<0.001)$ & $0.657,0.887(\mathrm{p}<0.001)$ \\
BC & 86 & $0.873(\mathrm{p}<0.001)$ & $\mathrm{y}=0.854 \mathrm{x}+0.1616$ & $0.535,1.356(\mathrm{p}<0.001)$ & $0.767,0.981(\mathrm{p}<0.001)$ \\
$\mathrm{AE}$ & 13 & $0.694(\mathrm{p}=0.008)$ & $\mathrm{y}=0.9383 \mathrm{x}+0.2617$ & $0.672,4.215(\mathrm{p}=0.011)$ & $0.161,0.867(\mathrm{p}=0.008)$ \\
$\mathrm{UN}$ & 34 & $0.813(\mathrm{p}<0.001)$ & $\mathrm{y}=0.7667 \mathrm{x}+0.5089$ & $0.110,1.716(\mathrm{p}=0.027)$ & $0.640,1.084(\mathrm{p}<0.001)$ \\
\hline
\end{tabular}

$\mathrm{y}$ refers to the CAP/CTM assay and $\mathrm{x}$ refers to the Cobas assay. $\mathrm{UN}=$ Ungenotyped samples.

against the mean values obtained by the two assays. The mean difference was $0.388 \log _{10} \mathrm{IU} / \mathrm{ml}$ and the SD was $0.377 \log _{10} \mathrm{IU} / \mathrm{ml}$. The difference in absolute values obtained by the two assays was $>1.0 \log _{10} \mathrm{IU} / \mathrm{ml}$ in $3.91 \%$ (7/179) of the tested samples. Subtyping showed these samples belonged to clades BC and AE. Further analysis by a paired $t$ test demonstrated that the mean difference was significantly different from $0(\mathrm{p}<0.001)$. This implies that on average, the Cobas quantitative values are higher than the CAP/CTM values. If the difference in values was normally distributed, one would expect to observe approximately $95 \%$ of them between 2 standard deviations of the mean. According to the Bland-Altman model, the limits of agreement were -0.367 and 1.143 $\log _{10} \mathrm{IU} / \mathrm{ml}$ (mean $\pm 2 \mathrm{SD}$ ), and $95.53 \%$ (171/179) of the difference values fell within this range for the limits of agreement. The remaining 8 samples were outside the limits of agreement yet 5 of these 8 samples exhibited higher quantitative values in the Cobas assay.

\section{Performance Comparison of the Cobas and}

CAP/CTM Assays for Different Clades

Among the 179 samples, $81.01 \%$ (145/179) were genotyped successfully, with 46 samples belonging to clade B', 86 to clade $\mathrm{BC}$ and the remaining 13 were determined to be part of clade AE. The correlation coefficients between the Cobas and CAP/CTM assays were $0.899,0.873$ and 0.694 for clades B', BC and AE, respectively, and significant correlations $(p<0.001)$ were observed for both assays on detecting a genetically diverse panel of samples in China. For each of the different clade sample groups, the fitted regression line differed significantly from the line of equality (table 1 ; fig. 3 ).

As shown in table 2, the mean differences plotted by Cobas-CAP/CTM in $\log _{10} \mathrm{IU} / \mathrm{ml}$ ranged from 0.046 to $0.458 \log _{10} \mathrm{IU} / \mathrm{ml}$. These differences were statistically sig- nificant for clade B', clade BC and ungenotyped samples $(p<0.001)$, whereas the mean difference in quantitation for clade AE was not significant $(\mathrm{p}=0.808)$. By plotting the regression equation (intercept $=0$ ), no great difference (difference ranged from 1.01 to $10.88 \%$ ) was found in clades B', BC or ungenotyped samples (table 2). Further Bland-Altman analysis revealed that the differences between the Cobas and CAP/CTM assays were within \pm 1 $\log _{10} \mathrm{IU} / \mathrm{ml}$ of the mean $\log _{10}$ values for the two assays in $95 \%$ of the tested samples (clade B' $0.330,-0.241 / 0.900$; clade BC 0.458, -0.217/1.133; clade AE 0.046, -1.282/1.374; ungenotyped $0.421,-0.323 / 1.16$; table 2 ; fig. 4 ).

\section{Discussion}

In this study, two commercial HIV-1 viral load assays were comparatively evaluated using untreated HIV-1-infected individuals from different clades prevalent in China. Although the two assays apply RT-PCR technology, the Cobas assay detects a signal at the end-point of the assay whilst the CAP/CTM test involves monitoring of a signal in real time. A significant advantage of the CAP/ CTM assay is the broad dynamic range of $40-10,000,000$ copies $/ \mathrm{ml}$. This range is significantly greater than that of the standard semi-automated Cobas assay [14]. Although the high agreement $(\kappa=1.000)$ of qualitative results between the CAP/CTM and Cobas assays was observed for 185 clinical samples, 5 quantitative results were beyond the linearity range for the Cobas test but still within the dynamic range for the CAP/CTM assay.

Previous studies in Western countries revealed the high correlation between the standard Cobas assay, the automated Cobas, and bDNA testing $[15,16]$. One study in China using samples from treated and untreated HIV1-infected individuals also indicated a high correlation 


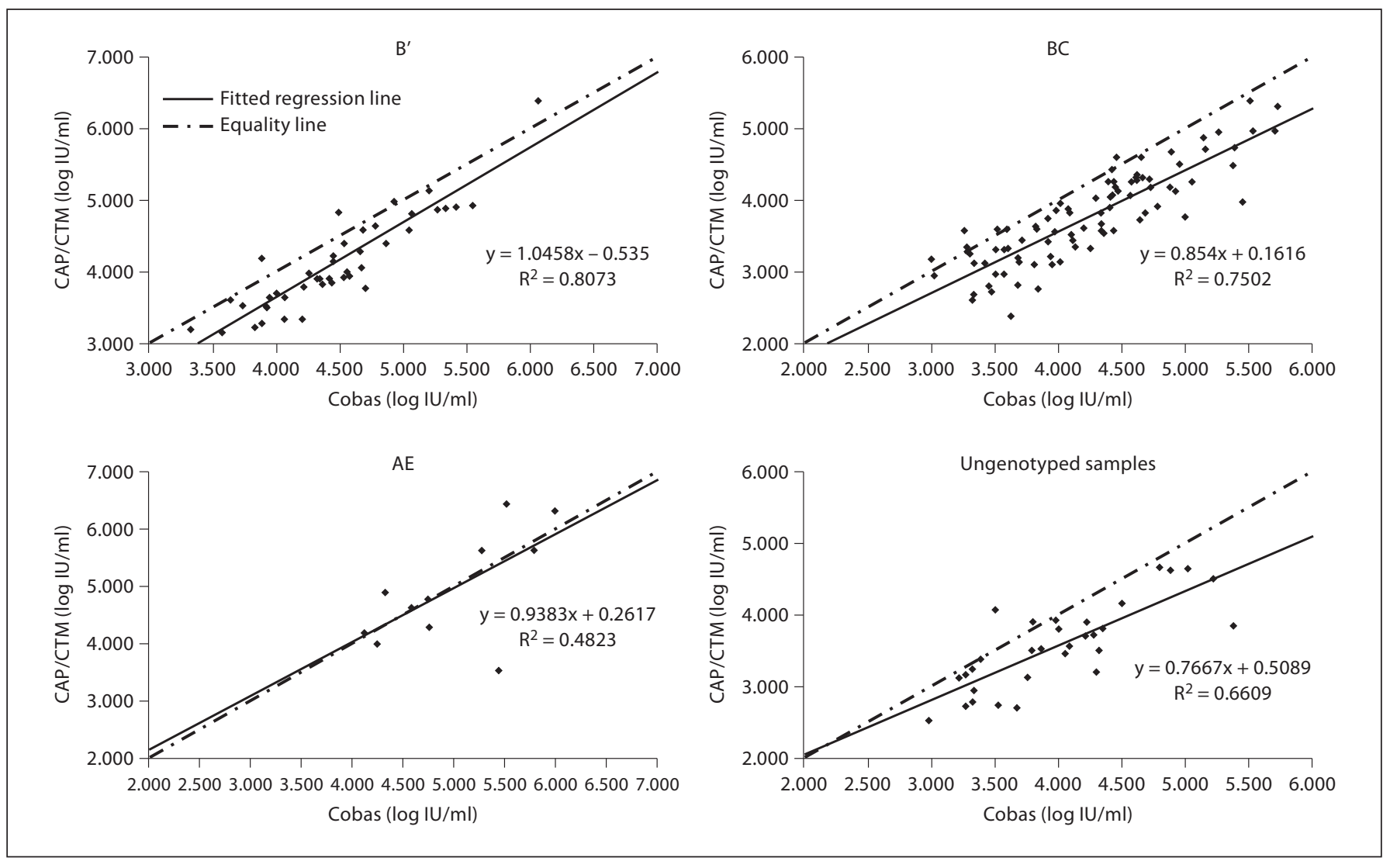

Fig. 3. Comparisons of the fitted regression lines and lines of equality for samples from different clades.

Table 2. HIV-1 RNA levels measured by the Cobas and CAP/CTM assays according to clade

\begin{tabular}{|c|c|c|c|c|c|c|c|c|c|}
\hline & \multirow[t]{2}{*}{$\mathrm{n}$} & \multicolumn{2}{|l|}{ Mean \pm SD } & \multirow{2}{*}{$\begin{array}{l}\text { Mean difference } \\
\text { Cobas-CAP/CTM }\end{array}$} & \multirow{2}{*}{$\begin{array}{l}\text { SD for } \\
\text { difference }\end{array}$} & \multirow{2}{*}{$\begin{array}{l}\text { Significance } \\
\text { (paired 2-tailed } \\
\text { t test) }\end{array}$} & \multirow{2}{*}{ Agreement } & \multirow{2}{*}{$\begin{array}{l}\text { Regression } \\
\text { equation } \\
(\text { intercept }=0 \text { ) }\end{array}$} & \multirow[t]{2}{*}{$|y-x| \div x$} \\
\hline & & $\begin{array}{l}\text { Cobas } \\
\log I U / m l\end{array}$ & $\begin{array}{l}\text { CAP/CTM } \\
\log \mathrm{IU} / \mathrm{ml}\end{array}$ & & & & & & \\
\hline Total & 179 & $4.310 \pm 0.671$ & $3.922 \pm 0.741$ & 0.388 & 0.377 & 0.000 & $95.53 \%(171 / 179)$ & $y=0.9109 x$ & $8.91 \%$ \\
\hline $\mathrm{B}^{\prime}$ & 46 & $4.481 \pm 0.556$ & $4.152 \pm 0.647$ & 0.330 & 0.285 & 0.000 & $91.30 \%(42 / 46)$ & $y=0.9281 x$ & $7.19 \%$ \\
\hline BC & 86 & $4.245 \pm 0.657$ & $3.787 \pm 0.648$ & 0.458 & 0.338 & 0.000 & $95.35 \%(82 / 86)$ & $y=0.8912 x$ & $10.88 \%$ \\
\hline $\mathrm{AE}$ & 13 & $4.980 \pm 0.682$ & $4.934 \pm 0.921$ & 0.046 & 0.664 & 0.808 & $92.31 \%(12 / 13)$ & $y=0.9899 x$ & $1.01 \%$ \\
\hline $\mathrm{UN}$ & 34 & $3.986 \pm 0.624$ & $3.565 \pm 0.588$ & 0.421 & 0.372 & 0.000 & $94.12 \%(32 / 34)$ & $y=0.8914 x$ & $10.86 \%$ \\
\hline
\end{tabular}

y refers to the CAP/CTM assay and $\mathrm{x}$ refers to the Cobas assay. $\mathrm{UN}=$ Ungenotyped samples.

and good agreement between the CAP/CTM and bDNA assays [20]. Similar to the above studies, a significant correlation $(\mathrm{R}=0.863, \mathrm{p}<0.001)$ between the Cobas and CAP/CTM assays was observed, although the fitted regression line differed significantly from the line of equal- ity ( $p<0.001)$. Analysis of agreement using the BlandAltman model revealed that the differences for $95.53 \%$ of the 179 samples within the dynamic range for both assays, were within the limits of agreement. Further analysis involved plotting the regression equation (intercept $=0$ ) 


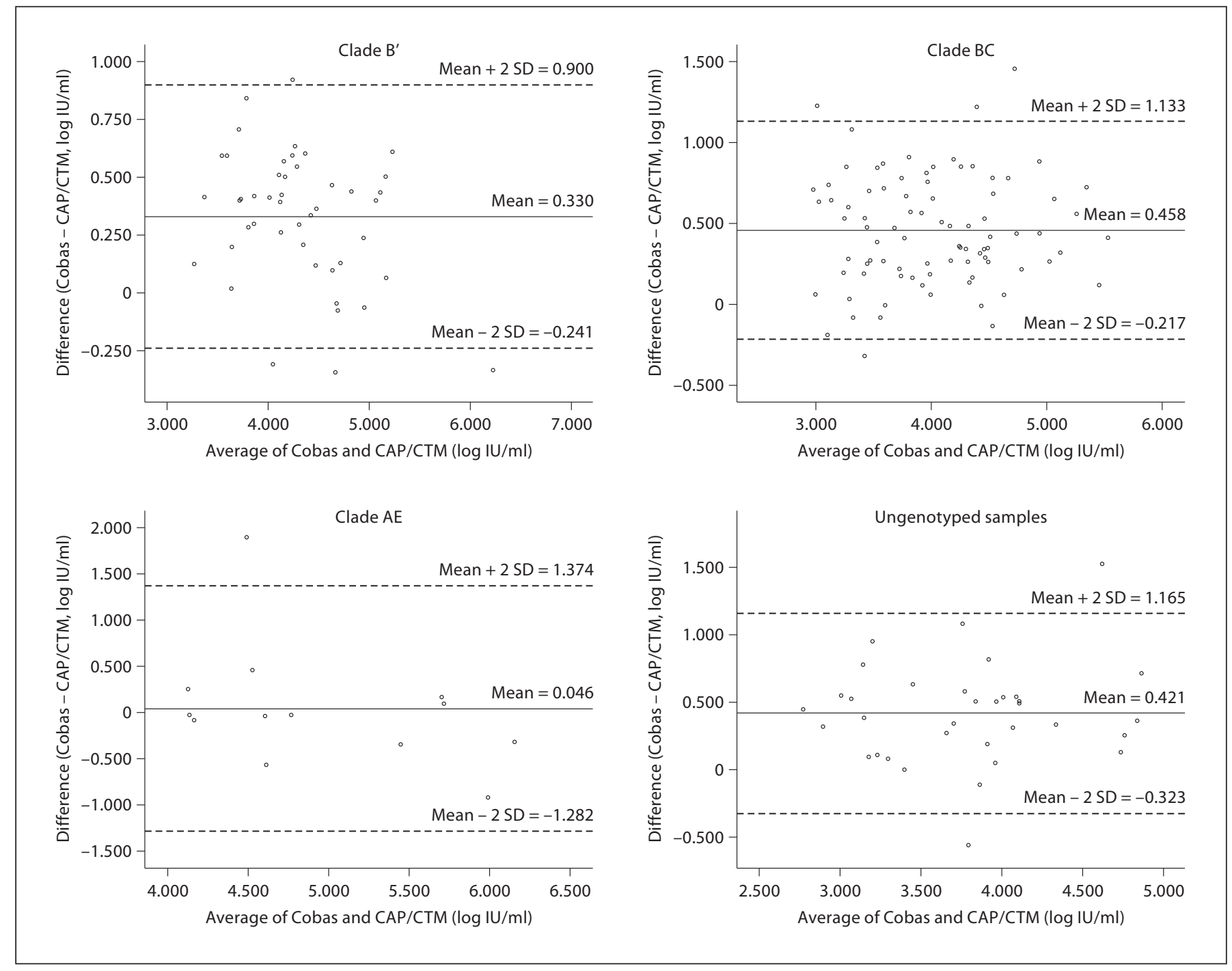

Fig. 4. Comparison of the agreements between the Cobas and CAP/CTM assays for samples from different clades.

and indicated no great difference (8.91\%) in the quantitative values for the Cobas and CAP/CTM assays.

The high level of genetic diversity and rapid rate of evolution characteristic of HIV-1, provides a significant challenge in the design of HIV-1 viral load assays for detection and quantitation of HIV-1 RNA. Those mutations located within primer- and probe-binding sites can reduce hybridization efficiency resulting in failed detection or inaccurate quantitation [21-23]. Ideally, a viral load assay should be capable of detecting and reliably quantifying HIV-1 RNA for all HIV-1 groups and subtypes. In this study, high agreement (91.30-95.35\%) by the Bland-Altman model and significant correlations
$(\mathrm{R}=0.694-0.899, \mathrm{p}<0.05)$ were observed for samples in clades B', BC and AE as well as ungenotyped samples. The present study indicated that reliable quantitative results can be obtained from HIV-1 samples prevalent in China using both the Cobas and CAP/CTM assays. No significant difference was found $(\mathrm{R}=0.694$, mean difference $=0.046, p=0.808$ ) for samples within clade $A E$, however it should be noted that the number of samples within clade AE was relatively small (13 samples). There is also the additional issue of whether there are mismatches between the HIV-1 clade AE sequences, and the primers and probes of the two assays, which remains unclear. Therefore, the performances of the Cobas and 

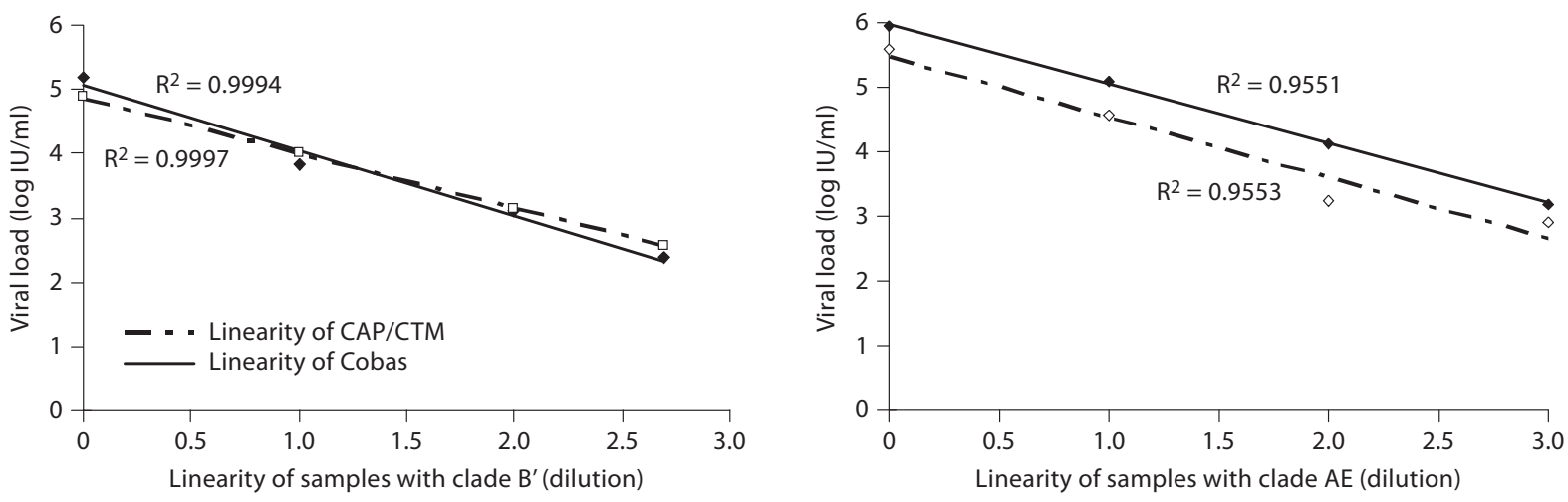

Fig. 5. Linearities of the Cobas and CAP/CTM assays for samples within clades B' and AE.

CAP/CTM assays for samples within clade AE may require further investigation.

To evaluate the performance of HIV-1 viral load assays, the linearity was compared. Several previous studies were completed to evaluate the linearity of Cobas and CAP/CTM assays $[17,20]$. For the Cobas assay, the linearity correlation coefficients were $0.9870,0.9995$ and 0.9995 for clades B', BC and AE, respectively. For the CAP/CTM assay, the linearity correlation coefficients were 0.9997 , 0.9989, and 0.9773 for clades B', BC and AE, respectively. The results indicated excellent linearities in detecting HIV-1 RNA within different clades for the CAP/CTM and Cobas assays.

In the present study, no sample was selected from ARV-treated patients; however our previous studies focusing on the impact of ART drugs on commercial HIV1 viral loads in China using the CAP/CTM HIV-1 test versus HIV-1 bDNA 3.0, and Abbott RealTime HIV-1 assay versus NucliSens HIV-1 easyQ, indicated that the ART drugs in China did not significantly affect the re- sults of these assays $[20,24]$. Whether the ART drugs affected the CAP/CTM and Cobas assays may need further investigation.

Currently, HIV-1 viral load assays are highly recommended by current guidelines as routine tools for monitoring HIV-1-infected patients in many laboratories. In the present study, a strong overall agreement and significant correlation between the CAP/CTM and Cobas assays was observed for quantifying HIV-1 RNA within different clades predominant in China from untreated HIV-1-infected individuals. Therefore, both the CAP/ CTM and Cobas assays are valid for monitoring HIV-1 viral load in routine clinical samples regardless of clade.

\section{Acknowledgments}

This study was supported by the National Key Study Item of '10th Five-Year-Projects' (No. 2004BA719A07). We would like to thank Mr. David Li and Ms. Min Zhong from the Shanghai office of Roche Diagnostics for technical assistance.

\section{References}

Performance of CAP/CTM and Cobas for Quantifying HIV-1 RNA in China
Curran JW, Jaffe HW, Hardy AM, Morgan WM, Selik RM, Dondero TJ: Epidemiology of HIV infection and AIDS in the United States. Science 1988;239:610-616.

-2 Ioannidis JP, Tatsioni A, Abrams EJ, Bulterys M, Coombs RW, Goedert JJ, et al: Maternal viral load and rate of disease progression among vertically HIV-1-infected children: an international meta-analysis. AIDS 2004; 18, 99-108.
Gulick RM, Mellors JW, Havlir D, Eron JJ, Gonzalez C, McMahon D, Richman DD, Valentine FT, Jonas L, Meibohm A, Emini EA, Chodakewitz JA: Treatment with indinavir, zidovudine, and lamivudine in adults with human immunodeficiency virus infection and prior antiretroviral therapy. $\mathrm{N} \mathrm{Engl}$ J Med 1997;337:734-739. 
4 Li TS, Tubiana R, Katlama C, Calvez V, Ait Mohand H, Autran B: Long-lasting recovery in CD4 T-cell function and viral-load reduction after highly active antiretroviral therapy in advanced HIV-1 disease. Lancet 1998; 351:1682-1686.

5 Notermans DW, Jurriaans S, de Wolf F, Foudraine NA, de Jong JJ, Cavert W, Schuwirth CM, Kauffmann RH, Meenhorst PL, McDade H, Goodwin C, Leonard JM, Goudsmit J, Danner SA, et al: Decrease of HIV-1 RNA levels in lymphoid tissue and peripheral blood during treatment with ritonavir, lamivudine and zidovudine. AIDS 1998; 12:167-173.

6 Lal RB, Chakrabarti S, Yang C: Impact of genetic diversity of HIV-1on diagnosis, antiretroviral therapy and vaccine development. Indian J Med Res 2005;121:287-314.

$\checkmark 7$ Fraf M, Shao Y, Zhao Q, Seidl T, Kostler J, Wolf H, Wagner R: Cloning and characterization of a virtually full-length HIV type 1 genome from a subtype B0-Thai strain representing the most prevalent $\mathrm{B}$-clade isolate in China. AIDS Res Hum Retrovirus 1998; 14:285-288.

8 Piyasirisilp S, McCutchan FE, Carr JK, Sanders-Buell E, Liu W, Chen J, Wagner R, Wolf H, Shao Y, Lai S, Beyrer C, Yu X-F: A recent outbreak of human immunodeficiency virus type 1 in southern China was initiated by two highly homogeneous, geographically separated strains, circulating recombinant form $\mathrm{AE}$ and a novel BC recombinant. J Virol 2000;74:11286-11295.

-9 Xing H, Qin GM, Feng Y, Liu G, Pan PL, Fan XJ, Shao YM: Identification and characterization of HIV-1 subtype D strain in China. Chin J Exp Clin Virol 1999;13:157-162.

10 Su L, Xing H, Yang HT, Luo XG, Shao YM: Identification and characterization of HIV-1 subtype A in China. Chin J Virol 1997;12: 265-268.
11 Mulder J, McKinney N, Christopherson C, Sninsky J, Greenfield L, Kwok S: Rapid and simple PCR assay for quantitation of human immunodeficiency virus type 1 RNA in plasma: application to acute retroviral infection. J Clin Microbiol 1994;32:292-300.

12 Vandamme AM, Dooren SV, Kok W, Goubau P, Fransen K, Kievits T, Schmit JC, Clercq ED, Desmyter J: Detection of HIV-1 RNA in plasma and serum samples using the NASBA amplification system compared with RNA-PCR. J Virol Methods 1995;52: 121-132.

13 Kern D, Collins M, Fultz T, Detmer J, Hamren S, Peterkin JJ, Sheridan P, Urdea M, White R, Yeghiazarian T, Todd J: An enhanced-sensitivity branched-DNA assay for quantification of human immunodeficiency virus type 1 RNA in plasma. J Clin Microbiol 1996;34:3196-3202.

14 Murphy DG, Cote L, Fauvel M, Rene P, Vincelette J: Multicenter comparison of Amplicor 1.5 COBAS AMPLICOR MONITOR version 1.5, Organon Teknika NucliSens QT with Extractor, and Bayer Quantiplex version 3.0 for quantification of human immunodeficiency virus type 1 RNA in plasma. J Clin Microbiol 2000;38:4034-4041.

15 Katsoulidou A, Petrodaskalaki M, Sypsa V, Papachristou E, Anastassopoulou CG: Evaluation of the clinical sensitivity for the quantification of human immunodeficiency virus type 1 RNA in plasma: comparison of the new COBAS TaqMan HIV-1 with three current HIV-RNA assays - LCx HIV RNA quantitative, VERSANT HIV-1 RNA 3.0 (bDNA) and COBAS AMPLICOR HIV-1 Monitor v1.5. J Virol Methods 2006;131:168174.

16 Schumacher W, Frick E, Kauselmann M, Maier-Hoyle V, van der Vliet R, Babiel R: Fully automated quantification of human immunodeficiency virus (HIV) type 1 RNA in human plasma by the COBAS AmpliPrep/ COBAS TaqMan system. J Clin Virol 2007; 38:304-312.
17 Wang Y, Song A, Xu S, Li X, Chong H, Zhao C, Nie J, Zhang C: The impact of HIV-1 genetic diversity in China on the measurement of viral load. J Med Virol 2008;80:1-8.

18 Kwok S, Sninsky JJ: PCR detection of human immunodeficiency virus type 1 proviral DNA sequences; in Persing DH, Smith TF, Smith FC, Tenover TJ, White TJ (eds): Diagnostic Molecular Biology: Principles and Applications. Washington, ASM Press, 1993.

19 Bland JM, Altman DG: Statistical methods for assessing agreement between two methods of clinical measurement. Lancet 1986;i:307-310.

20 Xu S, Song A, Nie J, Li X, Li J, Bao Z, Wang Y: Comparative evaluation of COBAS AmpliPrep/COBAS TaqMan HIV-1 test (CAP/ CTM) and VERSANT HIV-1 RNA 3.0 Assay (bDNA) for Quantitating HIV-1 Viral Loads in China. AIDS Res Hum Retrovirus 2008; 24:1365-1373.

$>21$ Barlow KL, Tosswill JHC, Parry JV, Clewley JP: Performance of the Amplicor human immunodeficiency virus type 1 PCR and analysis of specimens with false-negative results. J Clin Microbiol 1997;35:2846-2853.

22 Christopherson C, Sninsky J, Kwok S: The effects of internal rimer template mismatches on RT-PCR: HIV-1 model studies. Nucleic Acids Res 1997;25:654-658.

23 Swanson P, de Mendoza C, Joshi Y, Golden A, Hodinka RL, Soriano V, Devare SG, Hackett J Jr: Impact of human immunodeficiency virus type 1 (HIV-1) genetic diversity on performance of four commercial viral load assays: LCx HIV RNA Quantitative, AMPLICOR HIV-1 MONITOR v1.5, VERSANT HIV-1 RNA 3.0, and NucliSens HIV-1 QT. J Clin Microbiol 2005;43:3860-3868.

24 Xu S, Song A, Li X, Li J, Bao Z, Panyong M, Zhao Q: Youchun Wang. Performance of the Abbott RealTime HIV-1 assay for quantification of HIV-1 clades prevalent in China. J Clin Virol 2008;41:305-309. 